\title{
Element of Happiness by Al Ghazali and Relation in Islamic Psychospiritual
}

Norhashimah Yahya, Syed Hadzrullathfi Syed Omar, Siti Hajar Mohamad Yusoff, Mohd Hasrul Shuhari \& Muhammad Hafizi Rozali

To Link this Article: http://dx.doi.org/10.6007/IJARBSS/v10-i11/8202

DOI:10.6007/IJARBSS/v10-i11/8202

Received: 10 September 2020, Revised: 12 October 2020, Accepted: 19 November 2020

Published Online: 29 November 2020

In-Text Citation: (Yahya et al., 2020)

To Cite this Article: Yahya, N., Omar, S. H. S., Yusoff, S. H. M., Shuhari, M. H., \& Rozali, M. H. (2020). Element of Happiness by Al Ghazali and Relation in Islamic Psychospiritual. International Journal of Academic Research in Business and Social Sciences, 10(11), 1248-1253.

Copyright: (c) 2020 The Author(s)

Published by Human Resource Management Academic Research Society (www.hrmars.com)

This article is published under the Creative Commons Attribution (CC BY 4.0) license. Anyone may reproduce, distribute, translate and create derivative works of this article (for both commercial and non-commercial purposes), subject to full attribution to the original publication and authors. The full terms of this license may be seen at: http://creativecommons.org/licences/by/4.0/legalcode

Vol. 10, No. 11, 2020, Pg. 1248 - 1253

Full Terms \& Conditions of access and use can be found at http://hrmars.com/index.php/pages/detail/publication-ethics 


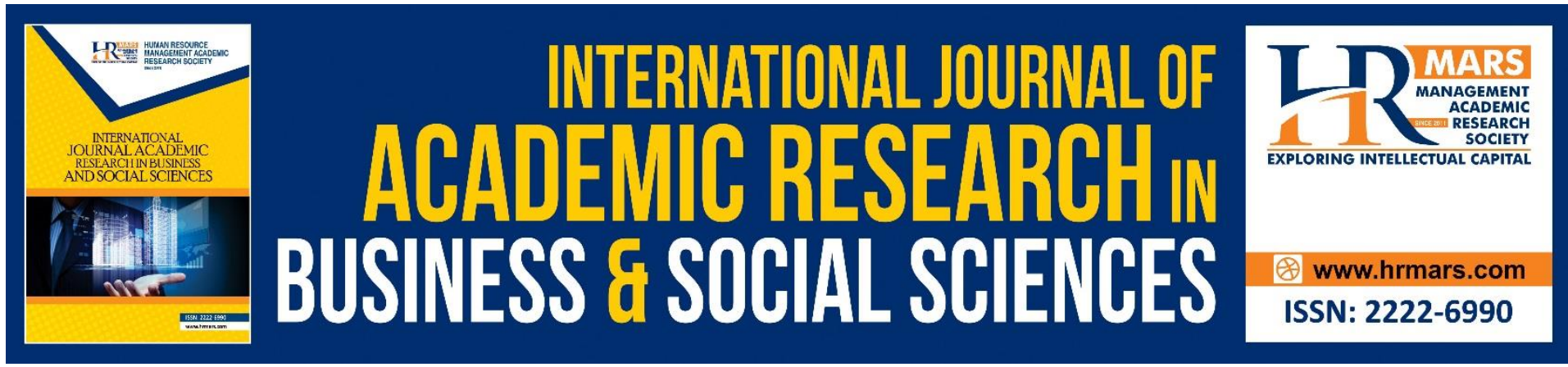

\title{
Element of Happiness by Al Ghazali and Relation in Islamic Psychospiritual
}

\author{
${ }^{1}$ Norhashimah Yahya, ${ }^{2}$ Syed Hadzrullathfi Syed Omar, ${ }^{2}$ Siti \\ Hajar Mohamad Yusoff, ${ }^{2}$ Mohd Hasrul Shuhari \& ${ }^{2}$ Muhammad \\ Hafizi Rozali
}

${ }^{1} \mathrm{PhD}$ Candidate, Faculty of Islamic Contemporary Studies, ${ }^{2}$ Faculty of Islamic Contemporary Studies, Universiti Sultan Zainal Abidin (UniSZA), Terengganu, Malaysia

\begin{abstract}
Happiness is one of the psychospiritual elements in human life. Currently, many people suffer from emotional disorders due to their unhappy souls. The guide for soul treatment from Allah s.w.t. can help freeing human beings from the symptoms of mental disorders that can disrupt the harmony of human life and the other God's creations. In order to obtain the guidance, it is crucial to study the teachings conveyed by the prophets as well as the ongoing guidance provided by the religious scholars as the heirs of the prophets. Therefore, the need for a review of the work left by previous scholars should be done in addition to the effort on understanding the guidelines found in the Qur'an and Hadith. The pearls of knowledge quoted by previous scholars, including Al Ghazali, put a lot of emphasis on the aspect of soul treatment for human beings. Qualitative approach using content analysis method found that the element of happiness according to Al Ghazali is one of the psychospiritual methods that can be utilized by the global community.
\end{abstract}

Keywords: Soul Treatment, Al Ghazali, Psychospiritual Methods

\section{Introduction}

Psychospiritual is a combination of psychological and spiritual terms. Psychology is a discipline that involves the scientific study of human mental processes and behaviour as well as knowledge of various human activities including problems encountered in life and treatment of such problems. Spiritual is an internal and soul element that is not physical (Sternberg, 1997)

While Islamic psychospiritual is a concept and method of treatment for mental disorders (nafs, ruh, qalb), mental (intellect), emotional ('atif) and moral behaviour (morals) based on resources and practices in Islam based on the Quran, al Sunnah, practice of the pious predecessors and knowledge that do not contradict Islamic principles aim to achieve happiness in this world and in the hereafter (Ghaffar, 2020).

Every human being is definitely bombarded with various problems. However, it is important to analyse the chosen solution in solving the problem encountered. Islam is a 
comprehensive religion. Not only does it contain true teachings, but every method of soul treatment is also outlined in Islam.

This can be further proved when some scholars also show that the stability of spiritual health must be based on the values set by religion which is also influenced by culture and practice in perfecting it. Thus, the spiritual element established by religion becomes one of the elements that could influence the change of a troubled individual because it is able to create significance and trust in human beings (Breitbart, 2020: 272).

The state of one's soul can be seen through attitudes, behaviours, self-appearance, speech and so on. When defiance and disobedience to the command of Allah SWT has been attached to a person's soul, heart, mind, senses and physical, the guidance of Allah SWT can no longer penetrate his spiritual. The effect of the disobedience causes the nature of a human being to be shackled in the soul. Eventually, his spiritual and physical became ill and could not perform the functions of true innate nature (Norlina, 2018: 1)

Due to the illness, unhappiness in human beings is growing. The effect is not only on the emotions, but also the behaviour that is expressed also shows a negative impact on the individual involved.

Al-Ghazali $(450 \mathrm{H})$ and western psychologists, such as Maslow (1970M) did not deny that it is part of human nature to have the desire of happiness in life. Every human being definitely wants to feel happy whether in the presence of family, husband or wife, children, friends, neighbours and society. This is undeniable because it is human nature to feel happy. In fact, it can be said that every time people will try to make themselves, their children and their families, the people around them and so on, to feel happy.

Happiness can be understood as a positive feeling or thing that can bring peace and satisfaction especially when every desire is fulfilled. Even happiness is also the main source of harmony in the household or family for a better life (Asih 2014, 3). Happiness can shape human behaviour to be positive. This is because positivity is resulted from emotional happiness. Without realizing it, behaviours and actions are also implemented positively. The author gives an overview of the relationship between emotional, cognitive and behavioural aspects in achieving happiness as shown in figure 1.

Figure 1: Relationship Between Emotional, Cognitive and Behavioral Aspects in Achieving Happiness
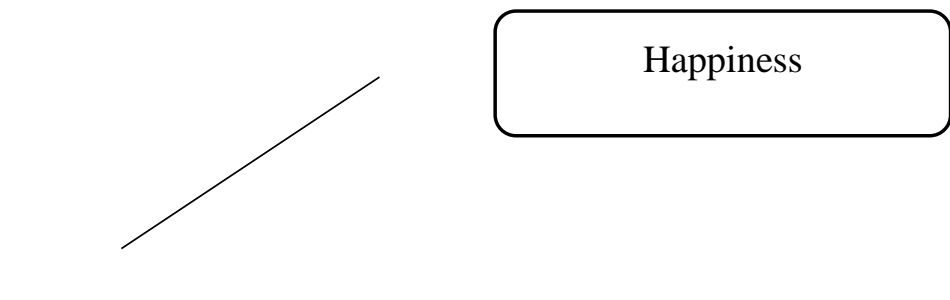

Emotional

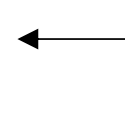

Cognitive

Behavioural 
The psychospiritual modules put forward by most researchers prove that Al Ghazali's theory is widely applied in the construction of psychiatric treatment modules (Salasiah, 2008). The psychospiritual concept can be attributed to the early Islamic scholar, al-Ghazali $(450 \mathrm{H})$. The three elements found in human beings are the soul, intellect and lust that is emphasized by Al Ghazali attracts researchers to explore these elements to produce effective treatment for the human soul.

Al Ghazali explains that the soul is a spiritual element that needs to be constantly cared for and purified because it is important for human inner health. In addition, human beings are also rational individuals who have intellect. The intellect in this context is also associated with the spiritual element. Elements of reason or rationality in humans refer to the ability to speak, understand, responsibility, and being able to make judgments and explanations. In addition to the soul and the intellect, lust is also, according to Al Ghazali, a spiritual element for human beings. Al Ghazali explains that the word lust has two meanings, namely anger and desire (Shakirah, 2008: 14)

The spirit is a calm soul that gives the effect of serenity (Sakinah) to the heart, mind, nafs and body. Qalb (spiritual heart) has emotional and thinking power. A good heart feels love, serenity, peace, and has a spiritual perception that can understand and feel the truth and knowledge from Allah swt. It is a determinant of human actions that are related to the soul, mind, nafs and can be seen through the behaviour of the body. The mind guides the human being to make the best choices in line with knowledge and experience guided by the heart. Nafs (Soul) is a calm soul that makes human beings fill their lives with pious deeds and efforts in taqarrub (approaching) to Allah s.w.t.

Meanwhile, the physical is a body that feels healthy, fresh, signs of relaxation and serenity when the heart, mind, and nafs, are at the best level as a servant of Allah s.w.t. On the other hand, the body feels pain, exhaustion, restlessness and tension when the heart, mind and nafs are at a low level of a human being.

Al Ghazali also quotes that happiness is born from a deep appreciation of Islam through faith and piety, understanding of belief and consolidation of knowledge. On the other hand, the happiness that is built on lust alone is a temporary happiness, despicable and brings destruction (Al-Ghazali, 1970: 185)

Due to that, al-Ghazali called for the theory of simplicity (al-tawasut) to balance human morality with a modest attitude and not to exceed the limits (Norzahidah \& Raihanah $2011,28)$. True happiness according to al-Ghazali is also meaningless when man fulfils material things or only worldly affairs. However, the ultimate happiness is when man reaches the perfection of the soul (Manam, Interview, 2016)

Meanwhile, Fadli (2004) stated that happiness cannot be measured by wealth of property, healthy body, high rank, impressive career and so on. However, happiness for an individual is when he has known himself, the purpose of life, understand the Sunnah and the trials of life and wisely deal with it (Fadli, 2004: 86; Alevriadou \& Massi, 2013).

In fact, al-Ghazali explains that happiness is interpreted as the unification between knowledge, deeds, spiritual and physical (arrow A). This unification is also in the human effort to strengthen faith and piety. It means these four things make man know Allah s.w.t. through noble morals and pious deeds. At the same time, human beings should always strive to strengthen knowledge and it is necessary to purify the heart first because through a pure heart, human beings will gain knowledge to achieve eternal happiness. If man had achieved happiness, the serenity of life would surely come without seeking. 
Furthermore, the unification between aqidah, syariah, and morality is also a priority for an individual to further strengthen faith and piety (arrow B). A firm belief and in line with the rules set by Allah s.w.t. to produce noble morals is important to make human beings as believers and pious.

Thus, this produces strong faith and piety in the soul (arrow C) which aims to achieve happiness. Knowledge as a guide to life as well as faith, law and morality must be in line with revelation to achieve true happiness and serenity. The author summarizes the aspects of happiness according to al-Ghazali as shown in Figure 2:

Figure 2: Elements to Achieve True Happiness through Al-Ghazali's Approach

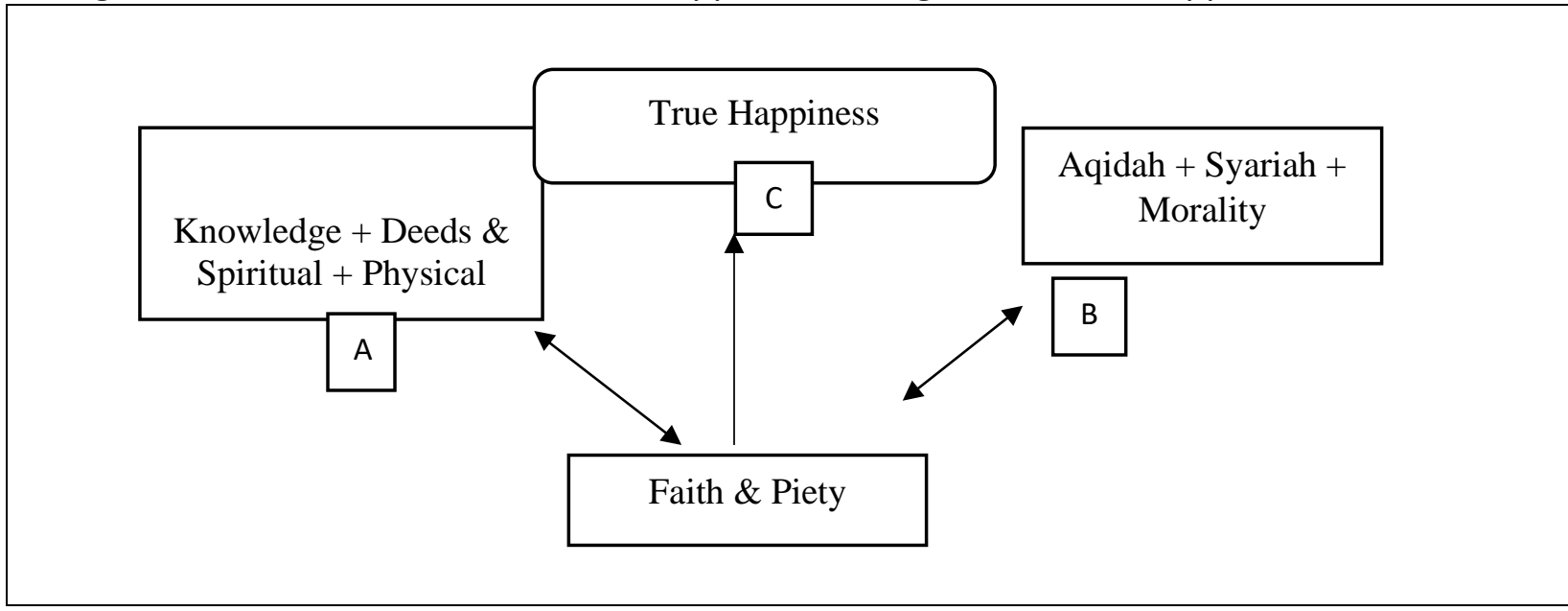

\section{Effects on the Unhappy Souls}

It can be observed that if happiness is difficult to be achieved, it is almost impossible for a person to have a calmness. While calmness is one of the important aspects in controlling emotions, especially when people are faced with problems. If observed, human beings who are restless in their souls are so affected by emotions that without realizing it, often actions are taken out of self-control.

The effect of this restless self is also one of the causes of the presence of stress in life. Stress can occur when a person is in a state of psychological irrationality or is in a state of restlessness. Even when one's heart becomes dirty as a result of disobedience to the command of Allah s.w.t. and being too lustful is also one of the causes of stress (Shahril 2013: 260).

The effective method of applying the module based on religious and spiritual elements is able to produce good results and be an alternative to the current method of allopathy treatment used to treat those with problems (Khairul et.al, 2014: 125).

\section{References}

Alevriadou, A., \& Massi, M. (2013). An Intervention Program Related to Reading Development - A Case Study of a Child with Williams Syndrome. Multilingual Academic Journal of Education and Social Sciences, 1(1), 86-100.

Surip, A. G. (2020). Kosep dan Kepentingan Psikoterapi Islam dalam Mendepani Cabaran Dunia Moden. Webinar Psikospiritual Islam Siri 1.

Al Ghazali, M. (1970), Khuluq al-Muslim. Riyadh: Dar al-Bayan. 
Miranti, A. (2014). Faktor-faktor pembentuk kebahagiaan dalam keluarga (konteks budaya Jawa dan pengaruh Islam). (Tesis sarjana yang tidak diterbitkan). Universitas Muhammadiyah Surakarta, Indonesia.

Breitbart, W. (2002). Spirituality and Meaning in Supportive Care: Spirituality and Meaning Centered Group Psychotherapy Interventions In Advanced Cancer. Support Care Cancer 20. Page 272-280.

Jodi, K. H. M., Mohamad, M. A., Seman, A. C. (2014), Penerapan Agama Dalam Modul Psikospiritual Dan Kesannya Terhadap Kesihatan Spiritual: Kajian Kes di Kompleks Dar Assaadah Kuala Lumpur. Jurnal Syariah, Jil 22. Bil 1. 107-127.

Sulaiman, M. F. (2004). Kebahagiaan Definisi dalam Islam. Kuala Lumpur: Utusan Publications \& Distributors Sdn.Bhd.

Othman, M. S. (2013). Keberkesanan modul pengurusan tekanan (MPT) bagi mengurus tekanan kerja dalam kalangan guru. (Tesis doktor falsafah yang tidak diterbitkan). Universiti Kebangsaan Malaysia, Selangor.

Akhir, N. S. M. (2008). Al-Ghazali and His Theory of The Soul: A Comparative Study. Pulau Pinang: Universiti Sains Malaysia.

Jaapor, N. Z., \& Azahari, R. (2011). Model keluarga bahagia menurut Islam. Jurnal Fiqh, 8, 2544.

Hamjah, S. H. (2008). Pendekatan dakwah al-irsyad al-nafsiyy menurut al-Ghazali: Satu kajian di Pusat Kaunseling Majlis Agama Islam Negeri Sembilan. (Tesis doktor falsafah yang tidak diterbitkan). Universiti Sains Malaysia, Pulau Pinang.

Muhamad, S. N. (2018). Psikoterapi Islam Konsep, Kaedah dan Panduan. Kuala Lumpur: Dewan Bahasa dan Pustaka.

Sternberg, R. J. (1997). Introduction to Psychology. Florida: Harcourt Brace \& Company. 